\title{
Staphylococcal flora of the oral cavity and dental prostheses before and after kidney transplantation. Part 1
}

\author{
Flora gronkowcowa jamy ustnej i protez stomatologicznych \\ przed i po przeszczepie narządowym nerki. Część 1
}

\author{
Krzysztof Majchrzak', Elżbieta Mierzwińska-Nastalska ${ }^{1}$, Grażyna Młynarczyk ${ }^{2}$, \\ Ksenia Szymanek-Majchrzak ${ }^{2}$
}

\author{
${ }^{1}$ Katedra Protetyki Stomatologicznej, Warszawski Uniwersytet Medyczny \\ Department of Prosthodontics, Medical University of Warsaw \\ Head: prof. dr hab. n. med. Elżbieta Mierzwińska-Nastalska \\ ${ }^{2}$ Katedra Mikrobiologii Lekarskiej, Warszawski Uniwersytet Medyczny \\ Department of Medical Microbiology, Medical University of Warsaw \\ Head: prof. dr hab. n. med. Grażna Młynarczyk
}

KEY WORDS:

kidney transplantation, denture plaque, Staphylococcal bacteria in oral cavity

\section{Summary}

Introduction. Staphylococcal bacteria through their ability to create biofilms and adhere to plastic surfaces easily inhabit foreign objects introduced into the body. Dentures, often used 24 hours a day, create conditions for the development and multiplication of microorganisms, being a convenient site for their accumulation. Patients with renal insufficiency and those who receive kidney transplants constitute a group at high risk of exposure to bacterial infections, and dental prostheses may be their potential source

Objective. To analyse the structure of colonization of dental prostheses and pharyngeal mucosa with Staphylococci in patients treated with kidney organ transplantation, and to assess the impact of prosthesis use and hygiene pattern on the species composition of the bacterial flora at the studied sites.

Material and methods. The material consisted of 278 samples of clinical material from patients using prostheses, which in the form of direct swabs were collected from the mucosal surface of
HASŁA INDEKSOWE:

przeszczep nerki, płytka protez, bakterie Staphylococcus w jamie ustnej

\section{Streszczenie}

Wstep. Bakterie Staphylococcus poprzez zdolność do tworzenia biofilmu i adhezji do tworzyw sztucznych łatwo zasiedlaja ciała obce wprowadzone do ustroju. Protezy stomatologiczne, użytkowane niejednokrotnie całodobowo, stwarzaja warunki do rozwoju i namnażania drobnoustrojów, stanowiac dogodne miejsce do ich akumulacji. Pacjenci z niewydolnościa nerek oraz otrzymujący przeszczep narządowy nerki, stanowia grupę o szczególnym ryzyku narażenia na zakażenia bakteryjne, a protezy stomatologiczne moga być jego potencjalnym źródtem.

Cel pracy. Analiza struktury kolonizacji protez zębowych i błony śluzowej gardła bakteriami Staphylococcus u pacjentów leczonych przeszczepem narzadowym nerki oraz ocena wptywu schematu użytkowania i higieny protez na sktad gatunkowy flory bakteryjnej badanych miejsc.

Material i metody. Materiat stanowito 278 próbek materiatu klinicznego od pacjentów użytkujących protezy, który w postaci wymazów bezpośrednich pobrano z powierzchni błony ślu- 
the pharynx and the mucosal side of the prosthesis plate from 57 patients treated with kidney organ transplantation (the study group) and 27 generally healthy people (the control group). In the study group, 28 patients were distinguished, in whom the swabs were taken three times in the period between 0 and 12 months after surgery. For isolated strains, identification and drug resistance examination were carried out. The results were subjected to statistical analysis.

Results. Staphylococci were isolated from the surface of the pharyngeal mucosa and prostheses with similar frequency in both groups, and the most common species was $S$. epidermidis, whose isolation rate reached 50\%. Among patients in the study group subjected to one-year follow-up, the incidence of $S$. epidermidis was progressively decreasing from $48.84 \%$ to $18.6 \%$. The $S$. aureus species was isolated from the surface of the prosthesis only in the case of the study group subjects. In the study group only the duration of denture use did affect the number of Staphylococcal strains on dentures, not prosthesis hygiene or the 24-hour period of use.

Conclusions. The Staphylococcal flora of the renal transplant recipients does not show significant differences in the colonization structure of denture surfaces and pharynx mucous membrane surfaces in comparison with the generally healthy people. The surface of the prosthesis plate promotes the accumulation and development of bacteria, conditioning a more stable microbiota than the surface of the pharyngeal mucosa. Improper use of prostheses may lead to an increase in colonization with Staphylococcus species.

\section{Introduction}

Chronic renal disease (CRD) is a multisymptomatic morbidity with the characteristics of a syndrome resulting from excretory and secretory insufficiency due to a reduced number of functional nephrons in the parenchyma. ${ }^{1}$ According to global estimates, there are currently $600 \mathrm{~m}$ people suffering zowej gardla i dośluzowej strony plyty protezy od 57 chorych leczonych przeszczepem narzadowym nerki (grupa badana) i 27 osób ogólnie zdrowych (grupa kontrolna). $W$ grupie badanej wyodrębniono 28 osób, u których wymazy byty wykonywane 3- krotnie w okresie 0 -12 miesięcy od operacji. Dla wyizolowanych szczepów przeprowadzono identyfikacje oraz oznaczenie lekooporności. Wyniki poddano analizie statystycznej.

Wyniki. Gronkowce izolowano z powierzchni błony śluzowej gardla i protez z podobna częstościa w obu grupach, a najczęstszym gatunkiem byt S. epidermidis, którego częstość izolacji dochodziła do 50\%. Wśród pacjentów grupy badanej poddanych rocznej obserwacji, wystepowanie S. epidermidis progresywnie malato z 48,84\% do $18,6 \%$. Gatunek S. aureus izolowano z powierzchni protez tylko w przypadku osób grupy badanej. Na wzrost liczby szczepów Staphylococcus na powierzchni protez osób grupy badanej nie miała wplywu higiena protez, niestosowanie przerwy nocnej, a jedynie czas użytkowania.

Wnioski. Flora gronkowcowa osób leczonych nerkozastępczo nie wykazuje znacznych różnic w strukturze kolonizacji powierzchni protez $i$ błony śluzowej gardła $w$ porównaniu z osobami ogólniezdrowymi. Powierzchnia plyty protezy sprzyja akumulacji i rozwojowi bakterii, warunkując bardziej stabilny mikrobiom niz powierzchnia błony śluzowej gardta. Niewtaściwe użytkowanie protez, może prowadzić do wzrostu kolonizacji gatunkami Staphylococcus.

\section{Wstęp}

Przewlekła choroba nerek (PchN) jest wieloobjawowym zespołem chorobowym wynikającym z upośledzenia funkcji wydalniczej i wydzielniczej spowodowanej zmniejszeniem liczby sprawnych nefronów w miąższu. ${ }^{1}$ Według światowych szacunków, na świecie żyje ponad 600 mln osób cierpiących na tę chorobę, 
from this disease, of which in Poland the number exceeds $4 \mathrm{~m}$ people. ${ }^{2-4}$ If untreated, CRD will lead to end-stage renal failure, necessitating the implementation of a kidney replacement treatment. According to current therapeutic standards, the most beneficial and financially viable therapy is organ transplant. ${ }^{5}$ Approximately, around one thousand kidney transplantation procedures are performed in Poland yearly (Poltransplant). The procedural efficacy is high due to many years of experience of transplant teams and the availability of the latest generation immunosuppressive drugs; in the majority of cases, the outcome will result in improvement of the patients' quality of life. ${ }^{6}$

Kidney transplantation, similarly to other organs, is burdened with a high risk of infective complications associated with the very procedure and the postoperative period. Most hospitalizations due to infections are observed in the first year after transplantation. ${ }^{7}$ Infections are reported to account for as many as $49-81 \%$ of patients worldwide. ${ }^{8,9}$ In the majority of cases, Staphylococcus species are implicated in $25-47 \%$ of all infections. ${ }^{10,11}$ Bacterial morbidity is determined by their virulence factors, in particular bacterial ability to form biofilm and adhere to plastic materials. ${ }^{12,13}$

Biofilm constitutes an organized special structure of bacterial and fungal microorganisms, mutually interacting, and with a common intent on survival. Biofilms form in living tissues and on plastic materials. In the case of denture users, deposition of a biofilm, termed denture plaque, on the prosthesis' surface is a constant process. The porous structure of the acrylic resin, which constitutes the basic material for the construction of most removable dentures, favours the accumulation of microorganisms. Their removal is often impossible with conventional methods of denture cleaning. ${ }^{14,15}$ Bacteria and fungi, ever-present on the acrylic material, may z czego w Polsce ponad 4 mln. ${ }^{2-4}$ Nieleczona PchN prowadzi do schyłkowej niewydolności nerek, co skutkuje koniecznością wdrożenia leczenia nerkozastępczego. Według obecnych standardów, najbardziej korzystną i uzasadnioną z ekonomicznego punktu widzenia formą terapii jest przeszczep narządowy. ${ }^{5} \mathrm{~W}$ Polsce wykonuje się rocznie około tysiąca przeszczepów nerki (Poltransplant). Skuteczność leczenia dzięki wieloletniemu doświadczeniu ośrodków transplantacyjnych oraz dostępności nowoczesnych leków immunosupresyjnych jest wysoka i w większości przypadków zakończona poprawą jakości życia chorych. ${ }^{6}$

Przeszczep narządowy nerki oraz innych organów obarczony jest jednak dużym ryzykiem powikłań infekcyjnych związanych zarówno z samym zabiegiem, jak i okresem poprzeszczepieniowym. Najwięcej hospitalizacji chorych z powikłaniami infekcyjnymi jest obserwowanych $\mathrm{w} 1$ roku po przeszczepie. ${ }^{7}$ Zgodnie $\mathrm{z}$ doniesieniami w piśmiennictwie światowym, problem zakażeń dotyczy nawet $49-81 \%$ pacjentów. 8 ,9 Wśród infekcji bakteryjnych znaczącą rolę odgrywają drobnoustroje należące do rodzaju Staphylococcus (gronkowce), odpowiedzialne za 25-47\% wszystkich zakażeń. ${ }^{10,11}$ Chorobotwórczość bakterii podyktowana jest m.in. czynnikami wirulencji bakterii, wśród których najbardziej znamiennymi są zdolność do wytwarzania biofilmu i adhezja do tworzyw sztucznych. ${ }^{12,13}$

Biofilm stanowi zorganizowaną, przestrzenną strukturę mikroorganizmów bakteryjnych i grzybiczych o wzajemnych interakcjach i wspólnym celu, jakim jest przetrwanie. Formowanie biofilmów odbywa się zarówno na tkankach żywych, jak i materiałach sztucznych. W przypadku użytkowników protez stomatologicznych, na ich powierzchni dochodzi do stałego odkładania biofilmu określanego mianem płytki protez (denture plaque). Porowata struktura akrylu, materiału stanowiącego element konstrukcyjny większości ruchomych uzupełnień 
contribute to the development of morbidities such as local inflammatory lesions (prosthetic stomatopathies, angular cheilitis, stomatitis) and systemic infections (pneumonia, bacteraemia). Patients undergoing a kidney transplant procedure are highly vulnerable to bacterial infections, hence the need to monitor their microbiological status. Swabs are not taken from dentures, and so there is no data concerning the bacteria colonizing the denture material at the time of the transplantation procedure or during the pharmacological phase of restoring the balance between smooth functioning of the immune system and the suppression of the organ rejection process.

\section{Aim of the study}

This part of the study will aim at determining the following research objectives:

- to analyse bacterial staphylococcal composition on the surface of dentures and pharyngeal mucosa of patients treated with a kidney transplant,

- to evaluate the influence of denturewearing scheme and their cleaning on the composition of bacterial flora at the examined sites.

\section{Material and methods}

The study material consisted of 278 clinical samples obtained between 2012 - 2017 from patients treated in the Infant Jesus Hospital in Warsaw. All the patients were removable denture-wearers. The samples were direct swabs from the pharyngeal mucosa and the denture plate contacting the mucosa, which were collected from:

- 57 patients who underwent a kidney transplantation procedure in the General and Transplantation Surgery Clinic,

- 27 systemically healthy individuals with no medication history who underwent a protetycznych, sprzyja akumulacji drobnoustrojów, których eliminacja jest niejednokrotnie niemożliwa do przeprowadzenia przy zastosowaniu konwencjonalnych metod higieny protez. ${ }^{14,15}$ Bakterie i grzyby stale obecne w tworzywie akrylowym mogą przyczyniać się do wywoływania chorób zarówno o charakterze miejscowych zmian zapalnych (stomatopatia protetyczna, zapalenie kątów ust, zapalenie jamy ustnej), jak i infekcji o dużo większym zasięgu układowym (zapalenie płuc, bakteremia). Pacjenci leczeni przeszczepem narządowym nerki stanowią grupę osób szczególnie podatnych na zakażenia bakteryjne, stąd niezmiernie istotne jest monitorowanie ich stanu mikrobiologicznego. Rutynowo nie wykonuje się wymazów z protez zębowych, przez co brak jest wiedzy na temat bakterii zasiedlających tworzywo protez zarówno na etapie przeszczepu, jak i w okresie farmakologicznego kształtowania równowagi między sprawnym funkcjonowaniem układu odpornościowego a supresją procesu prowadzącego do odrzucenia narządu.

\section{Cel pracy}

W niniejszej części opracowania podjęto tematykę, stanowiącą odpowiedź na następujące cele badania:

- analiza bakteryjnego składu gronkowcowego na powierzchni protez stomatologicznych i błony śluzowej gardła u pacjentów leczonych przeszczepem narządowym nerki;

- ocena wpływu schematu użytkowania i higieny protez na skład gatunkowy flory bakteryjnej badanych miejsc.

\section{Material i metody}

Badaniem objęto 278 próbek materiału klinicznego, uzyskanego w latach 2012- 2017 od pacjentów Szpitala Klinicznego Dzieciątka Jezus w Warszawie użytkujących ruchome 
prosthetic treatment in the Department of Prosthodontics.

The exclusion criteria included the presence of active inflammatory lesions, systemic therapy with antibiotics, the use of antifungal agents or corticosteroids in the past month preceding the collection of samples, or the use of mouthrinses or other preparations potentially affecting the oral bacterial flora in the period of ten days preceding the collection of samples. All the participants in the study gave their written informed consent. The consent form was enclosed with the research project, which was approved by the Bioethics Committee of the Medical University of Warsaw.

Before collecting the material for analysis, patients were interviewed and physical examination performed. Based on medical history, the patients' general health was assessed. In patients with a history of kidney transplant, the following additional data was obtained: type of kidney-replacement treatment, dialysis period, the primary cause of renal dysfunction, and - in the case of 28 patients subjected to a year-long monitoring - the regimen and type of immunosuppressive therapy. Dental history concerned the patients' dentures, time of their use, replacement frequency, the use of adhesive materials and denture-cleaning preparations, hygiene habits and the way the dentures were stored when not in use, namely at night.

Intra-oral examination primarily focused on oral hygiene, missing teeth, presence of inflammatory lesions on the mucous membrane, with particular emphasis on the prosthetic base. A modified Ambjörnsen's denture plaque index was applied to evaluate denture's hygienic condition. ${ }^{16}$

Swabs for the microbiological examination were collected from the surface of the mucosa at the following sites: anterior pharynx (palatal tonsil) and the acrylic plate of the upper denture contacting the mucosa. For this purpose, sterile sets with transporting medium were used. In uzupełnienia protetyczne. Materiał stanowiły wymazy bezpośrednie z powierzchni błony śluzowej gardła i dośluzowej strony płyty protezy pobrane od:

- 57 chorych leczonych przeszczepem narządowym nerki w Klinice Chirurgii Ogólnej i Transplantacyjnej;

- 27 osób ogólnie zdrowych i nieprzyjmujących żadnych leków, które odbywały leczenie protetycznie w Zakładzie Protetyki Stomatologicznej.

Kryteria wykluczenia udziału w badaniu obejmowały występowanie w jamie ustnej aktywnych zmian zapalnych, stosowanie antybiotykoterapii ogólnoustrojowo, środków przeciwgrzybiczych, kortykosteroidów w ciągu 1 miesiąca poprzedzającego pobranie materiału oraz stosowanie płukanek stomatologicznych lub innych preparatów mogących wpłynąć na zmianę flory bakteryjnej jamy ustnej na $10 \mathrm{dni}$ przed pobraniem. Wszyscy pacjenci, biorący udział w badaniu wyrazili świadomą zgodę na piśmie, którego formularz stanowił załącznik projektu badawczego pozytywnie zaopiniowanego przez Komisję Bioetyczną WUM.

Przed pobraniem materiału do analiz, zebrano wywiad i przeprowadzono badanie przedmiotowe. Na podstawie wywiadu ogólnomedycznego określano stan ogólny pacjentów, a dodatkowo u osób leczonych przeszczepem narządowym, także rodzaj dotychczasowego leczenia nerkozastępczego, długość trwania dializ i pierwotnej przyczyny niewydolności nerek oraz w przypadku 28 osób objętych roczną obserwacją - także dawki i rodzaj leków immunosupresyjnych. Wywiad stomatologiczny dotyczył posiadanych protez, czasu ich użytkowania, częstości wymiany, stosowania środków adhezyjnych, preparatów do higieny protez, nawyków higienicznych i sposobu przechowywania protez $\mathrm{w}$ przerwie nocnej.

W badaniu wewnątrzustnym zwracano uwagę na stan higieny jamy ustnej, rodzaj braków zębowych, występowanie zmian zapalnych 
28 kidney-transplant patients, the swabs were collected three times:

- swab sample $n^{\circ} 1$ - collected preoperatively before pharmacological prepping (collection 0 ),

- swab sample no 2 - collected at 6-9 weeks following the transplantation procedure (collection 1),

- swab sample no 3 - collected at 6-12 months postoperatively (collection 2).

The remaining 29 patients treated with a kidney transplantation procedure and 27 controls had their swabs taken once (collection $0)$. Marked and secured clinical samples were dispatched to a microbiological laboratory, and cultured within 48 hours of their collection.

Agar medium with addition of ram's blood and Chapman selective and differential growth medium for Staphylococcal flora was chosen. After 48 hours at the temperature of $37^{\circ} \mathrm{C}$ samples were isolated and a series of reduction cultures were performed. Species identification and drug-sensitivity profiles were marked by means of VITEK 2 device (Biomerieux, Francja), and the results were interpreted in accordance with EUCAST guidelines.

Analysis of results was undertaken in two main fields. The first one concerned comparison of variables between the study group (57 patients treated with a kidney transplant) and the controls (27 systemically healthy individuals), as well as microbiology of dentures and the surface of pharyngeal mucosa following a single collection of the clinical material. The second area of analyses focused on the group of 28 renal recipients for whom three subsequent collections were planned (further referred to as "the one-year period of observation"). Subsequent periods of observation were subjected to comparative analysis for the presence of Staphylococcal bacterial flora of pharyngeal and denture niches. na powierzchni błony śluzowej ze szczególnym uwzględnieniem podłoża protetycznego. Przeprowadzono ocenę higieny protez wykorzystując zmodyfikowany wskaźnik płytki wg Ambjörnsena. ${ }^{16}$

Wymazy do badania mikrobiologicznego pobierano z powierzchni błony śluzowej przedniej ściany gardła (migdałka podniebiennego) oraz powierzchni dośluzowej płyty akrylowej protezy górnej. W tym celu wykorzystano jałowe zestawy pobraniowe $\mathrm{z}$ podłożem transportowym. W przypadku pacjentów leczonych przeszczepem narządowym nerki, u 28 osób wymazy były pobierane trzykrotnie:

- I wymaz w dniu transplantacji narządowej przed przygotowaniem farmakologicznym do operacji (pobranie „,0”);

- II wymaz po okresie 6-9 tygodni od transplantacji (pobranie ,1");

- III wymaz po okresie 6-12 miesięcy od zabiegu (pobranie ,2").

Pozostałe 29 osób leczonych przeszczepem narządowym oraz pacjenci grupy kontrolnej (27 osób) miały wykonywane wymazy jednokrotnie (pobranie „0”). Oznaczone i zabezpieczone próbki materiału klinicznego przetransportowano do laboratorium mikrobiologicznego i w ciągu 48 godzin od pobrania wykonano posiewy.

Zastosowano podłoże agarowe $\mathrm{z}$ dodatkiem krwi baraniej oraz podłoże wybiórczo - różnicujące Chapmana ukierunkowane na florę bakteryjną z rodzaju Staphylococcus. Po $48 \mathrm{~h}$ w temperaturze $37^{\circ} \mathrm{C}$ przeprowadzono izolację oraz serie posiewów redukcyjnych. Przynależność gatunkową szczepów oraz ich profile lekowrażliwości oznaczano za pomocą urządzenia VITEK 2 (Biomerieux, Francja), interpretując wyniki zgodnie z wytycznymi EUCAST.

Analizę wyników podzielono na dwa zasadnicze obszary. Pierwszy dotyczył zestawienia zmiennych między grupami: badaną (57 chorych leczonych przeszczepem narządowym) i kontrolną (27 osób ogólnie zdrowych) oraz oceny mikrobiologii protez i powierzchni błony 
Statistical analysis of results was performed. The significance level was set for $p=0.05$. The interval variables were examined for normality of the Shapiro-Wilk test distribution and visually in histograms. The strength of relations between variables was measured with Pearson's linear correlation coefficient after checking if curvilinearity is present. The homogeneity of variance was checked with the Levene test. When the conditions of using a parametric test (e.g. Student's t) were not met, the comparison of variable distributions was performed with the Mann-Whitney test for two groups, or with Kruskal-Wallis for larger numbers. The median and quartiles were then interpreted instead of the mean and standard deviation. The interdependent tables were constructed for nonmeasurable variables. Relationships between variables were analysed by the Chi-square test. When the expected numbers were too small $(<5)$ even with the Cochrane criterion, the exact test was used. Significant relationships were interpreted numerically and in diagrams. Calculations were made with the STATISTICA 6.1 package.

\section{Results}

\section{Colonization of the mouth and dentures with Staphylococcal flora}

In swabs obtained in Collection 0, Staphylococci bacterial species were identified on the denture plates in $48(84 \%)$ renal transplant recipients and in 21 (81\%) generally healthy individuals. Similarly, in the pharyngeal location the same species were isolated in $38(67 \%)$ study patients and in $18(86 \%)$ controls. The number of strains isolated on dentures was higher in the study group than in the controls (Tab. 1), however, the difference was not statistically significant $(p=0.43)$. No statistically significant difference was observed in the number of strains isolated from the pharynx between the study group and śluzowej gardła po jednokrotnym pobraniu materiału klinicznego. Drugi obszar analiz, był dedykowany grupie 28 osób po przeszczepie nerki, które objęto okresem obserwacji obejmującym trzy kolejne pobrania materiału (celem uproszczenia $\mathrm{w}$ dalszej części publikacji zastosowano określenie: „roczny okres obserwacji”). Poszczególne okresy poddano analizie porównawczej w zakresie flory bakteryjnej gronkowcowej mikroniszy gardła i protezy.

W przeprowadzonym badaniu wykonano analizę statystyczną uzyskanych wyników. $\mathrm{W}$ pracy przyjęto graniczny poziom istotności $p=0,05$. Zmienne przedziałowe badano pod względem normalności rozkładu testem Shapiro-Wilka i wizualnie na histogramach. Siłę powiązań między zmiennymi mierzono współczynnikiem korelacji liniowej Pearsona po uprzednim sprawdzeniu czy nie występuje krzywoliniowość. Jednorodność wariancji sprawdzano testem Levene'a. Gdy nie spełnione były warunki stosowania testu parametrycznego (np. t-Studenta) porównanie rozkładów zmiennych wykonano testem Manna-Whitneya dla dwóch grup lub Kruskala-Wallisa dla większej ich liczby. Interpretowano wtedy medianę i kwartyle zamiast średniej i odchylenia standardowego. Dla zmiennych niemierzalnych konstruowano tabele wielodzielcze. Związki między zmiennymi analizowano testem Chikwadrat. Gdy liczności oczekiwane były za małe $(<5)$ nawet $\mathrm{z}$ uwzględnieniem kryterium Cochrane'e stosowano test dokładny. Istotne związki interpretowano liczbowo i na wykresach. Obliczenia wykonano przy pomocy pakietu statystycznego STATISTICA 6.1.

\section{Wyniki}

Kolonizacja jamy ustnej i protez stomatologicznych bakteriami Staphylococcus

Z wymazów wykonanych w pobraniu ,0”, bakterie należące do rodzaju Staphylococcus wykryto na powierzchni płyty protezy u 48 
Table 1. The number of strains isolated in study and control patients in a single swab ("0")

\begin{tabular}{|l|c|c|c|}
\hline \multicolumn{1}{|c|}{ Group } & Denture & Pharynx & Total \\
\hline Study & 48 & 38 & 86 \\
\hline Control & 21 & 18 & 39 \\
\hline Total & 69 & 56 & 125 \\
\hline
\end{tabular}

the controls $(\mathrm{p}=0.19)$.

In one-year observation of renal transplant recipients (collections $0,1,2$ ) differences were observed in the colonization of Staphylococcal bacterial strains in subsequent swabs. The detection of Staphylococci in collection 0 did not necessarily indicate their occurrence in subsequent collections and vice versa. In collection 1, which was undertaken at 1.5 to 3 months postoperatively, a decline in the frequency of Staphylococci isolation was observed for both denture and pharyngeal swabs, only to increase again in collection 2 . The described dependencies are given in Table 2.

\section{Analysis of the influence of factors related to denture use on the number of isolated strains}

\section{Hygiene of dentures}

As far as hygiene of dentures is concerned, which is a measure of their cleanness, significant differences were observed between the study group and the controls $(\mathrm{p}=0.003)$. Systemically healthy individuals tended to manifest much better hygiene in comparison with kidney recipients. Assessment of denture hygiene as "poor" was several times more frequent in the case of the study group members $(73.33 \%)$ in comparison with the controls (13.33\%). Generally healthy individuals manifested "good" hygiene almost twice more often than kidney recipients $(64.29 \%$ and $35.71 \%$, respectively) (Fig. 1). osób (84\%) leczonych przeszczepem narządowym nerki i 21 (81\%) osób ogólnie zdrowych. Analogicznie z powierzchni gardła izolowano gatunki Staphylococcus u 38 (67\%) pacjentów grupy badanej i 18 (86\%) grupy kontrolnej. Liczba szczepów izolowanych z protezy była średnio większa $w$ grupie badanej niż grupie kontrolnej (tab. 1), jednak różnica ta nie była statystycznie istotna $(p=0,43)$. Nie stwierdzono również istotnej różnicy w liczbie szczepów izolowanych z gardła pomiędzy grupą badaną i kontrolną $(\mathrm{p}=0,19)$.

W rocznej obserwacji chorych po przeszczepie nerki (pobranie „0”, „1”, „2”) zaobserwowano różnice w kolonizacji szczepami Staphylococcus w kolejnych wymazach. Wykrycie gronkowców w pobraniu ,0" nie było jednoznaczne z ich występowaniem w kolejnych pobraniach i na odwrót. W pobraniu „1”, które następowało w okresie 1,5 do 3 miesięcy po przeszczepie następował spadek w częstości izolacji gronkowców zarówno w przypadku wymazów z powierzchni protez, jak i gardła, aby następnie znowu wzrosnąć w pobraniu określanym jako „2”. Opisane zależności ilustruje tabela 2.

\section{Analiza wpływu czynników związanych $\mathrm{z}$ użytkowaniem protez zębowych na liczbę izolowanych szczepów}

\section{Higiena protez}

W zakresie higieny protez, stanowiącej miarę dbałości o czystość użytkowanych uzupełnień 
Ta b le 2 . The Number of strains isolated in study patients in three subsequent swabs collections for pharyngeal $(\mathrm{Ph})$ and denture $(\mathrm{D})$ microniches

\begin{tabular}{|c|c|c|c|c|c|c|c|c|c|}
\hline \multirow{2}{*}{\multicolumn{2}{|c|}{ Species }} & \multicolumn{2}{|c|}{ Swab 0} & \multicolumn{2}{|c|}{ Swab I } & \multicolumn{2}{|c|}{ Swab II } & \multicolumn{2}{|c|}{ Total } \\
\hline & & \multirow{2}{*}{$\frac{G}{3}$} & \multirow{2}{*}{$\frac{P}{3}$} & \multirow{2}{*}{$\frac{G}{5}$} & \multirow[t]{2}{*}{$\mathrm{P}$} & \multirow{2}{*}{$\frac{G}{2}$} & \multirow{2}{*}{$\frac{P}{3}$} & \multirow{2}{*}{$\frac{G}{10}$} & \multirow{2}{*}{$\begin{array}{c}\mathrm{P} \\
10\end{array}$} \\
\hline & $\mathrm{N}$ & & & & & & & & \\
\hline 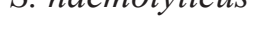 & $\%$ & $8.11 \%$ & $8.33 \%$ & $8.52 \%$ & $10.00 \%$ & $6.67 \%$ & $8.33 \%$ & & \\
\hline \multirow{2}{*}{ S. epidermidis } & $\mathrm{N}$ & 21 & 22 & 14 & 15 & 8 & 17 & 43 & 54 \\
\hline & $\%$ & $56.76 \%$ & $45.83 \%$ & $51.85 \%$ & $50.00 \%$ & $26.67 \%$ & $47.22 \%$ & & \\
\hline \multirow{2}{*}{ S. lentus } & $\mathrm{N}$ & 2 & 4 & 3 & 2 & 2 & 3 & 7 & 9 \\
\hline & $\%$ & $5.41 \%$ & $8.33 \%$ & $11.11 \%$ & $6.67 \%$ & $6.67 \%$ & $8.33 \%$ & & \\
\hline \multirow{2}{*}{ S. hominis } & $\mathrm{N}$ & 1 & 2 & 0 & 2 & 3 & 1 & 4 & 5 \\
\hline & $\%$ & $2.70 \%$ & $4.17 \%$ & $0.00 \%$ & $6.67 \%$ & $10.00 \%$ & $2.78 \%$ & & \\
\hline \multirow{2}{*}{ S. aureus } & $\mathrm{N}$ & 2 & 5 & 2 & 0 & 5 & 4 & 9 & 9 \\
\hline & $\%$ & $5.41 \%$ & $10.42 \%$ & $7.41 \%$ & $0.00 \%$ & $16.67 \%$ & $11.11 \%$ & & \\
\hline \multirow{2}{*}{ S. capitis } & $\mathrm{N}$ & 1 & 1 & 0 & 1 & 0 & 0 & 1 & 2 \\
\hline & $\%$ & $2.70 \%$ & $2.08 \%$ & $0.00 \%$ & $3.33 \%$ & $0.00 \%$ & $0.00 \%$ & & \\
\hline \multirow{2}{*}{ S. warneri } & $\mathrm{N}$ & 5 & 6 & 0 & 4 & 7 & 6 & 12 & 16 \\
\hline & $\%$ & $13.51 \%$ & $12.50 \%$ & $0.00 \%$ & $13.33 \%$ & $23.33 \%$ & $16.67 \%$ & & \\
\hline \multirow{2}{*}{ S. lugdunensis } & $\mathrm{N}$ & 2 & 1 & 0 & 0 & 0 & 0 & 2 & 1 \\
\hline & $\%$ & $5.41 \%$ & $2.08 \%$ & $0.00 \%$ & $0.00 \%$ & $0.00 \%$ & $0.00 \%$ & & \\
\hline \multirow{2}{*}{ S. saprophyticus } & $\mathrm{N}$ & 0 & 1 & 1 & 0 & 2 & 0 & 3 & 1 \\
\hline & $\%$ & $0.00 \%$ & $2.08 \%$ & $3.70 \%$ & $0.00 \%$ & $6.67 \%$ & $0.00 \%$ & & \\
\hline \multirow{2}{*}{ S. gallinarum } & $\mathrm{N}$ & & 0 & & 1 & & 0 & & 1 \\
\hline & $\%$ & & $0.00 \%$ & & $3.33 \%$ & & $0.00 \%$ & & \\
\hline \multirow{2}{*}{ S. xylosus } & $\mathrm{N}$ & & 1 & & 0 & & 0 & & 1 \\
\hline & $\%$ & & $2.08 \%$ & & $0.00 \%$ & & $0.00 \%$ & & \\
\hline \multirow{2}{*}{ S. vitulinus } & $\mathrm{N}$ & & 0 & & 2 & & 1 & & 3 \\
\hline & $\%$ & & $0.00 \%$ & & $6.67 \%$ & & $2.78 \%$ & & \\
\hline \multirow{2}{*}{ S. cohnii } & $\mathrm{N}$ & & 1 & & 0 & & 0 & & 1 \\
\hline & $\%$ & & $2.08 \%$ & $0.00 \%$ & & & $0.00 \%$ & & \\
\hline \multirow{2}{*}{ S. equorum } & $\mathrm{N}$ & & 0 & 0 & & & 1 & & 1 \\
\hline & $\%$ & & $0.00 \%$ & $0.00 \%$ & & & $2.78 \%$ & & \\
\hline \multirow{2}{*}{ S. vitulinus } & $\mathrm{N}$ & 0 & & 2 & & 1 & & 3 & \\
\hline & $\%$ & $0.00 \%$ & & $7.43 \%$ & & $3.33 \%$ & & & \\
\hline Total & $\mathrm{N}$ & 37 & 48 & 27 & 27 & 30 & 36 & 94 & 114 \\
\hline
\end{tabular}


The next step was to analyse the impact of denture hygiene of the number of strains in the studied microniches. Separate comparative analyses were performed for the study group and the controls. Regarding the effect of the quality of denture hygiene on the number of strains individually for the study group and the controls no significant dependencies were noted $(p>0.05)$. Comparative analysis revealed statistical significance for the pharyngeal microniche $(\mathrm{p}=0.037)$. In the case of renal transplant patients, $40 \%$ of subjects with "poor" hygiene and $60 \%$ with "good" or "average" hygiene, had two or more Staphylococcal strains. Among the controls, the isolation of two or more strains from the pharynx concerned $25 \%$ of subjects with "poor" hygiene, and 75\% with "good" or "average" hygiene.

\section{Duration of denture wear}

Organ-recipients on average utilized their dentures for 5.26 years $(0.5-15)$ whereas the systemically healthy subjects for 7.7 years (1$20)$. When the number of strains colonizing a denture and the duration of its use were compared, a statistically significant difference was revealed in the study group $(\mathrm{p}=0.03)$. In $77.78 \%$ of cases when dentures were utilized for a period shorter than 5 years, only one Staphylococcal strain was isolated. If the period exceeded 5 years, a single strain was identified only in $22.22 \%$ of cases. A similar observation was not reported among the controls $(\mathrm{p}=0.52)$.

\section{Circadian use of dentures}

A total of $52.6 \%$ subjects in the study group (30 patients) and $38.5 \%$ of the controls (10 patients) reported that they leave their denture in the mouth for the night. Seventeen organrecipients (29.8\%) and 16 generally healthy individuals $(61.5 \%)$ complied with the recommended protocol in which a nightly protetycznych, stwierdzono występowanie istotnych różnic między grupą badaną i kontrolną ( $p=0,003)$. Osoby ogólnie zdrowe wykazywały lepszą higienę w porównaniu z pacjentami leczonymi przeszczepem narządowym. Higiena protez określona jako „zła” występowała wielokrotnie częściej w przypadku pacjentów grupy badanej $(73,33 \%)$ w porównaniu do osób z grupy kontrolnej (13,33\%). Osoby ogólnie zdrowe charakteryzowały się „,dobrą" higieną prawie dwukrotnie częściej niż pacjenci leczeni przeszczepem narządowym (odpowiednio 64,29\% do 35,71\%) (ryc. 1).

Kolejnym krokiem analizy była ocena wpływu higieny protez na liczbę szczepów w badanych mikroniszach. Analizy przeprowadzono osobno dla grupy badanej i kontrolnej oraz porównując je między sobą. Rozpatrując wpływ jakości higieny protez na liczbę szczepów osobno dla grupy badanej i kontrolnej nie stwierdzono istotnych związków ( $p>0,05)$. W ocenie porównawczej między grupami istotność statystyczna wystąpiła w zakresie mikroniszy gardła $(\mathrm{p}=0,037)$. W przypadku pacjentów poddanych przeszczepowi narządowemu, u 40\% osób ze „złą” higieną i 60\% osób z higieną „dobrą” lub „przeciętną”, występowały 2 lub więcej szczepów gronkowców. W grupie kontrolnej izolacja dwóch lub więcej szczepów z powierzchni gardła dotyczyła $25 \%$ osób z higieną ,złą” oraz 75\% osób z higieną „dobrą” lub ,przeciętną”.

\section{Czas użytkowania protez}

U pacjentów leczonych przeszczepem narządowym czas użytkowania protez wynosił średnio 5,26 lat (0,5-15), natomiast u osób ogólnie zdrowych 7,7lat (1-20). W zestawieniu między liczbą szczepów zasiedlających protezę a czasem użytkowania, stwierdzono istotną statystycznie dodatnią zależność dotyczącą grupy badanej $(p=0,03)$. W 77,78\% przypadków protez użytkowanych w czasie do pięciu lat występował jeden szczep Staphylococcus, natomiast z protez powyżej pięciu lat izolowano 
break is required and the denture stored in dry conditions. When both groups are compared for the number of strains present on the denture plate in relation to the way the denture was utilized, significant differences were observed $(p=0.05)$. In the study group, only one strain occurred twice as often in cases of continuous denture use (30.77\%). In $69.23 \%$ of cases, two or more strains were isolated when compared with the controls. There, the percentage was $16.67 \%$ (one strain) and $83.33 \%$ (two or more strains), respectively (Tab. 3). No significant dependence was observed in the study group $(p=0.29)$ and the controls $(p=0.06)$ when the impact of the circadian wear of dentures on the number of species colonizing the acrylic plate was examined.

\section{Staphylococcal species isolated on the pha- ryngeal surface and the denture plate}

In the course of the research, fourteen Staphylococcal species were isolated, comprising 360 bacterial strains (Tab. 4). In collection 0 , the species with the highest incidence in both groups was Staphylococcus epidermidis (S. epidermidis). In the study group, its incidence on dentures accounted for $40.2 \%$, and in the controls $-35.1 \%$. So was the case with pharyngeal swabs: S. epidermidis was present with the incidence of $48.2 \%$ in patients following organ transplantation and $41.7 \%$ in healthy controls. S. aureus (14.9\%), S. warneri $(10.3 \%)$ or $S$. heamolyticus $(9.2 \%)$ were identified on dentures of patients in the study group; however, in the control group, apart from the aforementioned $S$. epidermidis, $S$. warneri strains (37.2\%) were mostly isolated. $S$. epidermidis dominated in the pharyngeal location, followed by $S$. aureus, $S$. warneri and S. lentus strains (Tab. 4).

When all the collections are analysed on a yearly basis, kidney transplant patients had the same Staphylococcal species both on the pharyngeal mucosa and denture plates as in pojedynczy szczep tylko w $22,22 \%$. Podobnych obserwacji nie odnotowano $\mathrm{w}$ grupie kontrolnej $(p=0,52)$.

\section{Użytkowanie protez całodobowo}

Pozostawienie protez zębowych w jamie ustnej $\mathrm{w}$ trakcie przerwy nocnej zgłaszało $52,6 \%$ osób grupy badanej (30 pacjentów) i $38,5 \%$ osób grupy kontrolnej (10 pacjentów). Zalecany schemat użytkowania obejmujący przerwę nocną i przechowywanie protez w środowisku suchym występował u 17 osób leczonych przeszczepem $(29,8 \%)$ i u 16 osób ogólnie zdrowych (61,5\%). Porównując obie grupy w liczbie szczepów obecnych na powierzchni protezy w zależności od schematów ich użytkowania stwierdzono istotne różnice $(\mathrm{p}=0,05)$. $\mathrm{W}$ grupie badanej prawie dwa razy częściej występował tylko jeden szczep (30,77\%) u osób użytkujących protezy bez przerwy nocnej i w 69,23\% przypadków dwa lub więcej szczepów $\mathrm{W}$ porównaniu $\mathrm{z}$ grupą kontrolną, gdzie ten odsetek wynosił odpowiednio $16,67 \%$ (jeden szczep) i 83,33\% (dwa lub więcej szczepów) (tab. 3). Analizując wpływ całodobowego użytkowania protez na liczbę szczepów kolonizujących tworzywo, nie stwierdzono istotnego związku w grupach badanej $(\mathrm{p}=0,29)$ i kontro$\operatorname{lnej}(p=0,06)$.

\section{Gatunki Staphylococcus izolowane z po- wierzchni gardla i płyty protezy}

W toku prowadzonych badań wyizolowano 14 gatunków gronkowców, składających się na 360 szczepów bakteryjnych (tab. 4). W pobraniu określonym jako „0” najczęściej występującym gatunkiem w obu grupach był Staphylococcus epidermidis (S. epidermidis). $\mathrm{W}$ grupie badanej jego częstość w przypadku protezy wynosiła $40,2 \%$, a w grupie kontrolnej $35,1 \%$. Podobnie w wymazach $\mathrm{z}$ gardła, S. epidermidis występował z częstością 48,2\% u osób leczonych przeszczepem narządowym i 41,7\% osób ogólnie zdrowych. Na protezach 
Ta b le 3. The number of strains isolated on denture plate relative to their use (nightly break, circadian)

\begin{tabular}{|c|c|c|c|c|c|c|}
\hline \multirow{2}{*}{$\begin{array}{c}\text { Circadian } \\
\text { use }\end{array}$} & \multicolumn{5}{|c|}{ Study } & \multicolumn{3}{c||}{ Control } \\
\cline { 2 - 7 } & One strain & $\begin{array}{c}\text { Two or more } \\
\text { strains }\end{array}$ & Total & One strain & $\begin{array}{c}\text { Two or more } \\
\text { strains }\end{array}$ & Total \\
\hline no & 10 & 12 & 22 & 9 & 6 & 25 \\
\hline yes & 8 & 18 & 26 & 1 & 5 & 6 \\
\hline
\end{tabular}

Ta b le 4. Staphylococcal species isolated on denture plate and pharyngeal mucosa in the study and control subjects in collection " 0 " swabs

\begin{tabular}{|c|c|c|c|c|}
\hline \multirow{2}{*}{ Species } & \multicolumn{2}{|c|}{ Denture 0} & \multicolumn{2}{|c|}{ Pharynx 0} \\
\hline & Study Group \% & Control Group \% & Study Group \% & Control Group \% \\
\hline S. aureus & 14.9 & - & 8.9 & 12.5 \\
\hline S. auricularis & - & 2.7 & - & - \\
\hline S. capitis & 5.7 & 5.4 & 5.4 & 8.3 \\
\hline S. cohnii & 1.2 & - & 1.8 & - \\
\hline S. epiderdmidis & 40.2 & 35.1 & 48.2 & 41.7 \\
\hline S. haemolyticus & 9.2 & 2.7 & 1.8 & 4.2 \\
\hline S. hominis & 8.1 & 5.4 & 5.4 & 4.2 \\
\hline S. lentus & 6.9 & 2.7 & 8.9 & 16.7 \\
\hline S. lugdunensis & 1.2 & - & 3.6 & - \\
\hline S. pasteuri & - & 2.7 & - & 4.2 \\
\hline S. saprophyticus & 1.1 & 2.7 & - & - \\
\hline S. sciuri & - & 2.7 & - & - \\
\hline S. warneri & 10.3 & 37.8 & 16.1 & 8.3 \\
\hline S. xylosus & 1.2 & - & - & - \\
\hline
\end{tabular}

collection 0 (S. epidermidis, S. warneri, $S$. heamolyticus and $S$. epidermidis, S. warneri, $S$. aureus, respectively). As for the dominant strains on the surface of dentures, there were no significant colonization differences in subsequent collections (Fisher's accuracy test $\mathrm{p}=0.46)$. In the pharynx, the colonization pacjentów grupy badanej stwierdzano również często gatunki, takie jak $S$. aureus (14,9\%), $S$. warneri $(10,3 \%)$ czy S. heamolyticus $(9,2 \%)$, natomiast w grupie kontrolnej poza wspomnianym $S$. epidermidis, były to głównie szczepy $S$. warneri $(37,2 \%)$. W przypadku powierzchni błony śluzowej gardła poza dominującym 


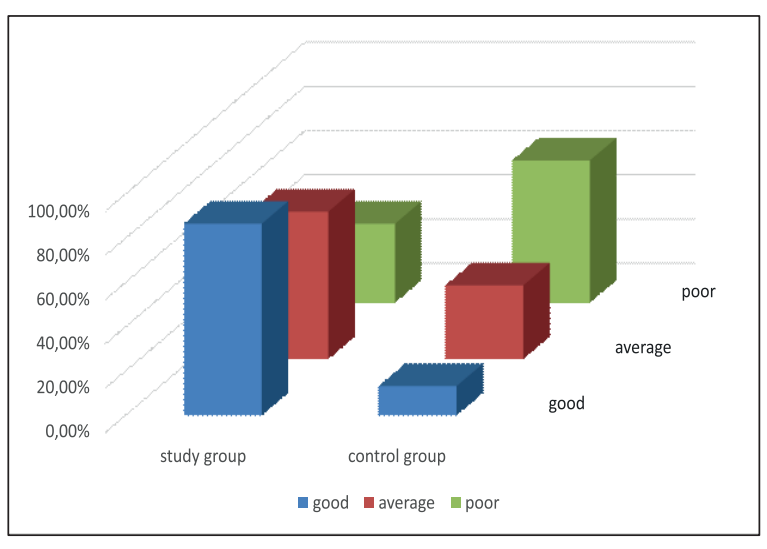

Fig. 1. Condition of denture hygiene in the study and the control groups.

Ryc. 1. Wykres stanu higieny protez w grupie badanej $i$ kontrolnej.

incidence of the three most frequent strains (S. epidermidis, S. warneri, S. heamolyticus) significantly varied in time $(\mathrm{p}=0.015)$. A progressive decline in the incidence of $S$. epidermidis strains from $48.84 \%$ in collection 0 to $18.60 \%$ in collection 2 was noted. At the same time, following the initial drop beyond the detection level in collection 1, it rose to $58.33 \%$ in collection 2 . The participation of $S$. haemolyticus strains following an initial rise from $30 \%$ to $50 \%$ in collection 1, dropped to $20 \%$ in collection 2 (Fig. 2).

The analysis of correlations of the total number of strains in subsequent collections in the population of kidney recipients revealed that they were strongly positive. Almost complete dependency was observed in the case of the number of strains isolated on the denture plate, which is confirmed by $r \geq 0.95$ indices for all examined collection periods. However, high, or very high, correlations between collections were determined for the number of strains isolated from the throat. All of these correlations have a high significance level $(\mathrm{p}=0.000)$, and reflect the tendency that a relatively constant number of strains are maintained during the one-year period following organ transplant.

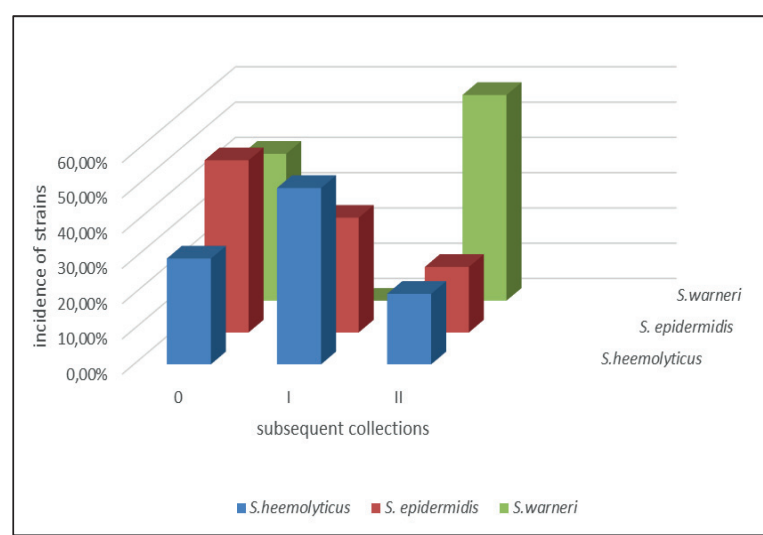

Fig. 2. Variability of the number of selected strains over the one-year period.

Ryc. 2. Zmienność liczby wybranych szczepów na przestrzeni roku.

gatunkiem $S$. epidermidis, w obu grupach izolowano często szczepy $S$. aureus, $S$. warneri i S. lentus (tab. 4).

Analizując wszystkie pobrania w rocznym okresie obserwacji dotyczące chorych po przeszczepie nerki stwierdzono, iż zarówno na powierzchni błony śluzowej gardła, jak i na powierzchni protezy najczęściej pojawiały te same gatunki Staphylococcus co w pobraniu ,0”, (odpowiednio S. epidermidis, S. warneri, $S$. heamolyticus i S. epidermidis, S. warneri, $S$. aureus). Pomiędzy dominującymi szczepami powierzchni protez nie występowały istotne różnice $\mathrm{w}$ kolonizacji w kolejnych pobraniach (test dokładny Fishera $\mathrm{p}=0,46$ ). W przypadku powierzchni gardła częstotliwość kolonizacji trzech najczęstszych szczepów (S. epidermidis, S. warneri, S. heamolyticus) istotnie się zmieniała w czasie $(\mathrm{p}=0,015)$. Zaobserwowano progresywny spadek częstości występowania szczepów S. epidermidis z 48,84\% w „0" pobraniu do $18,60 \% \mathrm{w}, 2$ ” pobraniu. W tym samym czasie częstość szczepów $S$. warneri po początkowym spadku do stanu niewykrywalności w ,1" pobraniu, wzrosła do 58,33\% w ,2" pobraniu. Udział szczepów $S$. haemolyticus po początkowym wzroście z 30\% do 50\% w „1”, spadł do $20 \% \mathrm{w}, 2$, pobraniu (ryc. 2). 


\section{Discussion}

Staphylococcal bacteria, when in balance with the host's immune system, are everpresent on the surface of the human body, thus preventing the growth of transient bacterial species. These characteristics are typical of the so-called residential flora; Streptococci constitute its main component. According to a multitude of reports in world literature, 100\% of the population manifest Staphylococci on the mucous membranes of the alimentary tract (oral cavity) or the respiratory system (nasal cavity). ${ }^{18-20}$ However, the presence of these bacteria in locations other than the skin is still treated as transient. ${ }^{21}$ Transient flora, as a rule, yields to other species of residential flora, in their competition for niches; it is also being forced out by the human immune system, and manifests poor adaptation to physical and chemical conditions of the newly colonized location. ${ }^{13}$ Numerous Staphylococcal species are also characterized by an affinity to plastic materials and formation of biofilms on their surfaces. ${ }^{23}$ Foreign bodies, including dental prostheses, are generally predestined to be colonized with Staphylococci. ${ }^{23}$ The conducted studies compare transplant candidates (collection "0") with generally healthy patients observing that Staphylococci were isolated with comparable frequency on the pharyngeal mucosa in both groups. Insignificant differences concerned denture plates, but were not confirmed by statistical analysis. In many instances, Staphylococci were present selectively on the pharyngeal and denture microniches, rarely in both locations simultaneously. In patients monitored for a year, the number of strains identified in subsequent collections varied with time, demonstrating upward and downward fluctuations with regard to frequency of isolation. These observations are consistent with the nature of Staphylococcal bacteria, whose presence in the mouth is transient displaying
W analizie korelacji między ogólną liczbą szczepów w kolejnych pobraniach w populacji osób po przeszczepie nerki, stwierdzono silne związki dodatnie. Prawie pełna zależność obserwowana była w przypadku liczby szczepów izolowanych z protezy, o czym świadczą wskaźniki $r \geq 0,95$ dla wszystkich porównywanych okresów pobrań. Wysokie lub bardzo wysokie korelacje między pobraniami stwierdzano natomiast dla liczby szczepów izolowanych z gardła. Wszystkie powyższe związki są wysoce istotne $(p=0,000)$ i świadczą o tendencji do utrzymania względnie stałej liczby szczepów na przestrzeni jednego roku od operacji przeszczepu narządowego.

\section{Dyskusja}

Bakterie należące do rodzaju Staphylococcus będąc $\mathrm{w}$ równowadze $\mathrm{z}$ układem odpornościowym gospodarza, są stale obecne na zewnętrznych powłokach ludzkiego ciała zapobiegając rozrostowi gatunków bakterii, które występują tam tylko przejściowo. ${ }^{17}$ Opisane powyżej cechy są charakterystyczne dla tzw. flory rezydentnej, której głównym składnikiem w przypadku jamy ustnej są bakterie należące do rodzaju Streptococcus. Pomimo, iż liczne badania opisane w literaturze światowej wskazują, iż nosicielstwo gronkowców na błonach śluzowych układu pokarmowego (jama ustna) czy oddechowego (jama nosowa) występuję $\mathrm{w}$ populacji badanych $\mathrm{z}$ częstością sięgającą $100 \%,{ }^{18-20}$ to występowanie tych bakterii w innych rejonach niż skóra traktowane jest nadal jako przejściowe. ${ }^{21}$ Flora przejściowa $\mathrm{z}$ reguły ustępuje w rywalizacji o miejsce $\mathrm{z}$ innymi gatunkami flory rezydentnej, jest również wypierana przez ludzki układ odpornościowy oraz wykazuje słabą adaptację do warunków fizyko-chemicznych panujących w nowo zasiedlonej lokalizacji. ${ }^{22}$ Liczne gatunki gronkowców charakteryzują się ponadto powinowactwem do tworzyw sztucznych i tworzeniem na 
a variety of compositions. Staphylococci on the denture plate or pharyngeal mucosa may be present or not, relative to factors that include age, diet, oral $\mathrm{pH}$, application of local antimicrobial or antifungal agents, systemic diseases. ${ }^{24,25}$ Due to their porous structure, dentures constitute a reservoir for a plethora of bacterial and fungal species, both commensal and pathogenic. ${ }^{26}$

Staphylococci fundamentally do not pose a threat to generally healthy people and when they colonize oral or nasal cavities they fail to produce clinical symptoms. Certain species including $S$. aureus, $S$ epidermidis, $S$. haemolyticus, $S$. lugdunensis possess a pathogenic potential under favourable conditions. Breaking the continuity of oral mucosa in consequence of dental procedures or administered medication facilitates transfer of oral bacteria to the bloodstream and organs away from the mouth. In transplant patients on immunosuppression such a situation may contribute to the occurrence of health- or lifethreatening events as well as to the functional deterioration of the received organ. ${ }^{27,28}$

In the present studies, hygiene practices of the removable denture-users differed among the study subjects and the controls. Patients following renal transplant tended to care less for the cleanness of their dentures than their healthy counterparts. This may be due to the fact that the controls were recall patients, presenting many times at the Prosthodontic Department of a Teaching Hospital, where students and their supervisors pay particular attention to hygienic issues. Patients treated with a renal transplant were usually not subjected to such meticulous dental care, mainly concentrating on other general health issues. When the number of strains is compared with the quality of hygiene in individual groups, no significant correlation was revealed ( $p>0.05$ ); however, when the reciprocal comparison is performed, correlations became evident, and concerned ich powierzchniach biofilmów. ${ }^{13}$ Ciała obce, w tym protezy stomatologiczne wprowadzone do ustroju są więc predysponowane do kolonizacji bakteriami Staphylococcus. ${ }^{3} \mathrm{~W}$ przeprowadzonych badaniach porównując grupę chorych przed przeszczepem (pobranie ,0") oraz pacjentów ogólnie zdrowych zaobserwowano, iż gronkowce $\mathrm{z}$ błony śluzowej gardła izolowano z podobną częstością w obu grupach. Nieznaczne różnice dotyczyły powierzchni protez, jednak analiza statystyczna ich nie potwierdziła. W wielu przypadkach bakterie Staphylococcus występowały wybiórczo w mikroniszy gardła lub protezy, rzadziej w obu miejscach jednocześnie. U pacjentów objętych roczną obserwacją, liczba szczepów izolowanych z poszczególnych pobrań zmieniała się w czasie, wykazując spadki i wzrosty częstości izolacji. Powyższe obserwacje są zgodne z naturą bakterii Staphylococcus, które w jamie ustnej zachowują się jak flora przejściowa o znacznej zmienności w składzie. Gronkowce zarówno na powierzchni protez, jak i na błonie śluzowej gardła mogą być obecne lub nie występować wcale i jest to zależne od czynników, takich jak wiek, dieta, ph jamy ustnej, stosowanie miejscowych środków przeciwbakteryjnych, przeciwgrzybiczych czy choroby ogólnoustrojowe. ${ }^{24,25}$ Protezy stomatologiczne ze względu na swoją porowatą strukturę, stanowią rezerwuar bakterii i grzybów licznych gatunków zarówno komensalnych, jak i patogennych. ${ }^{26}$

Bakterie należące do rodzaju gronkowców zasadniczo nie stanowią zagrożenia dla osób ogólnie zdrowych i kolonizując jamę ustną czy nosową nie wywołują objawów klinicznych. Część gatunków jak S. aureus, S epidermidis, S. haemolyticus, S. lugdunensis ma jednak potencjał wywoływania chorób, gdy pojawią się sprzyjające ku temu warunki. Przerwanie ciągłości błony śluzowej jamy ustnej na skutek zabiegów stomatologicznych lub przyjmowanych leków powoduje przedostawanie się bakterii z 
pharyngeal microniche $(\mathrm{p}=0.037)$. Statistically, a higher number of strains $(\geq 2)$ was noted in patients with poor hygiene in the study group than among the controls. In healthy individuals, lack of care regarding denture hygiene was less frequent when compared with an increased number of species. It has to be clearly stressed that the studies were qualitative, and did not cover any methods typically used to assess the impact of a variety of factors on the number of individual bacterial cells. Still, a conclusion may be drawn that the quality of denture hygiene does not impact bacterial species composition, and in the case of pharyngeal mucosa, the results are inconsistent requiring further studies and analyses.

Another characteristic feature potentially influencing the rise in the number of strains on the denture plate was the time period the denture was utilized. In kidney recipients, a significant increase in the number of isolated strains relative to the longer duration of denture wear was noted. A similar dependency was not observed among healthy individuals, who utilized their dentures on average for more than two years longer than kidney recipients. Due to high sorption of the acrylic material, and adverse impact of removable dentures on the prosthetic base, they should be replaced on a regular basis every couple of years. It has been demonstrated that the time of denture wear is in direct proportion to the increase of the Plaque Index, the incidence of periodontitis and the need for exodontia. ${ }^{29}$ In that light, chronically-ill patients require special dental care encompassing instruction for denture care, cleaning and storage protocols, periodic relining, or denture replacement. In the present study, the interview revealed that many wearers do not comply with the recommendation for the nightly break, which creates favourable conditions for bacterial and Candida spp. growth on the acrylic plate. Statistical comparative analysis revealed that circadian intra-oral use jamy ustnej do krwi i dalej do odległych organów. U pacjentów po przeszczepie, przyjmujących leki immunosupresyjne może się to przyczynić do występowania stanów zagrażających ich zdrowiu lub życiu oraz pogorszenia funkcji otrzymanego narządu. ${ }^{27,28}$

W prezentowanych badaniach higiena użytkowników ruchomych protez stomatologicznych była różna w grupie badanej i kontrolnej. Pacjenci leczeni przeszczepem narządowym nerki manifestowali słabszą dbałość o czystość protez niż osoby ogólnie zdrowe. Powyższy wynik może być podyktowany faktem, iż osoby należące do grupy kontrolnej to pacjenci zgłaszający się często po raz kolejny do leczenia protetycznego w placówce dydaktycznej, gdzie studenci i nauczający lekarze zwracają szczególną uwagę na kwestie higieny uzupełnień protetycznych. Osoby leczone nerkozastępczo z reguły takiej opieki stomatologicznej nie posiadały, a ich uwaga była skupiona głównie na problemach natury ogólnozdrowotnej. Analiza wyników zestawienia liczby szczepów $\mathrm{z}$ jakością higieny w poszczególnych grupach nie wykazała istotnych związków $(p>0,05)$, jednak już w porównaniu grup, zależności te miały miejsce i dotyczyły mikroniszy gardła $(\mathrm{p}=0,037)$. Tu statystycznie częściej stwierdzano większą liczbę szczepów $(\geq 2)$ u osób ze złą higieną należących do grupy badanej niż kontrolnej. W grupie osób ogólnie zdrowych, niska dbałość o higienę protez występowała rzadziej w zestawieniu ze zwiększoną liczbą szczepów. Należy wyraźnie zaznaczyć, iż przeprowadzone badania miały charakter jakościowy i nie obejmowały metod, na podstawie których można by było zbadać wpływ różnych czynników na liczbę komórek poszczególnych bakterii. Z powyższych obserwacji można jednak wywnioskować, iż jakość higieny protez nie wpływa na bakteryjny skład gatunkowy, a w przypadku powierzchni błony śluzowej gardła jest to niejednoznaczne i wymaga dalszych badań i analiz. 
of dentures may have a higher impact on the number of strains collecting on the denture plate of generally healthy individuals than those of kidney recipients. In this case, the test's significance level $(p=0.055)$ slightly exceeded the generally accepted value of $p=0.05$, which means that one has to be cautious in drawing conclusions concerning these differences. When it comes to international studies, O'Donnell $L E$ et al. $^{26}$ reported other species of bacteria claiming that in circadian denture users the number of Streptococci pneumoniae, bacteria responsible for pneumonia, on the denture plate is higher than in users practising a nightly break. Removable dentures should be subjected to hygienic practices and stored in dry ventilated conditions. ${ }^{30}$ With the denture out of the mouth, the prosthetic base undergoes mechanical cleansing by the tongue, air is accessed, the surface is regenerated, and storing in dry conditions prevents excessive proliferation of microorganisms, some of which dry up and die, and in the case of anaerobes, presence of oxygen leads to their extinction.

Staphylococci, which were isolated in the present study, are species regarded as harmless for the humans (S. lentus, S.hominis, $S$. capitis), as well as ones potentially pathogenic if the immune status is compromised, or the body's flora balance is disturbed ( $S$. aureus. $S$. epidermidis, S. lugdunensis, S. haemolyticus). The most frequently isolated species, both in the study and the control group, was S. epidermidis, with similar occurrence on the denture plate and pharyngeal mucosa. This species, being an integral component of epidermal flora and frequently colonizing the mucosa of the alimentary tract and airways, plays a significant role as a regulator of these complex bacterial ecosystems, preventing excessive growth of other microbial species. ${ }^{31}$ These benign characteristics of $S$. epidermidis, previously regarded as completely harmless, have now been confronted with the second nature of this species,
Kolejną ocenianą w badaniu cechą mającą potencjalny wpływ na wzrost liczby szczepów na powierzchni protezy był jej czas użytkowania. W grupie chorych leczonych nerkozastępczo stwierdzono istotny wzrost liczby izolowanych szczepów wraz z dłuższym czasem użytkowania protezy. Podobnej zależności nie zaobserwowano u osób zdrowych, które użytkowały protezy średnio ponad 2 lata dłużej niż pacjenci grupy badanej. Z uwagi na nasiąkliwość tworzywa akrylowego oraz negatywny wpływ protez osiadających na podłoże protetyczne, powinny one być wymieniane regularnie co kilka lat. Dowiedziono, iż wraz z czasem użytkowania danej protezy, wzrasta wskaźnik płytki, częstość zapalenia przyzębia oraz konieczność ekstrakcji zębów. ${ }^{29} \mathrm{~W}$ tym kontekście, pacjenci przewlekle chorzy powinni być otoczeni szczególną opieką stomatologiczną, która uwzględniałaby edukację w zakresie metod higieny protez, schematu ich mycia, przechowywania oraz okresowych podścieleń lub wymiany na nowe. W niniejszych badaniach zarówno w grupie badanej, jak i kontrolnej stwierdzono z wywiadu, iż wiele osób nie stosuje przerwy nocnej, co stwarza dogodne warunki do rozrostu bakterii i grzybów drożdżopodobnych w tworzywie akrylowym płyty protezy. Analiza statystyczna wykazała, iż w porównaniu grup całodobowe przetrzymywanie protez w jamie ustnej może mieć większy wpływ na liczbę szczepów na powierzchni protezy osób ogólnie zdrowych niż leczonych nerkozastępczo. W tym przypadku poziom istotności testu $\mathrm{p}=0,055$ nieznacznie przekroczył wartość przyjętą zwyczajowo $(p=0,05)$, co powoduje, iż należy ostrożnie podchodzić do wnioskowania o występowaniu powyższych różnic. W literaturze światowej badacze O'Donnell $L E$ i wsp. ${ }^{26}$ opisali obserwacje dotyczące innych gatunków baterii stwierdzając, że na protezie osób użytkujących je całodobowo, liczba np. Streptococcus Pneumoniae, bakterii odpowiedzialnych za zapalenie płuc, jest większa niż 
whose pathogenic potential is now believed to be almost identical to that of $S$. aureus. ${ }^{32}$ Staphylococcus causes infection primarily in individuals with a compromised immune system, including the elderly, chronically ill patients, chemotherapy recipients, or those on immunosuppressants. ${ }^{33,34}$ Severe $S$. epidermidis infections are nosocomial in character, and are related to the presence of biomaterials in the body such as catheters, endoprosthesis, prosthetic heart valves. ${ }^{35}$ Pathogenicity of $S$. epidermidis is determined by its virulent potential. MLST (Multilocus sequence typing), PFGE (Pulsed-field Gel Electrophoresis) or RAPD (Random Amplification of Polymorphic DNA) genetic studies make it possible to detect whether the given strain possesses virulent genes. ${ }^{36}$ S. epidermidis characteristic feature is the ability to pass these genes onto other species, such as $S$. aureus, which by acquiring them become more resistant to environmental factors, potentially including a multitude of antibiotics used in modern therapies. ${ }^{37}$

Staphylococcus aureus is a microorganism of special significance in medicine due to its participation in the etiopathogenesis of frequent nosocomial infections. ${ }^{38}$ In generally healthy population, the number of its carriers in the nasopharyngeal cavity is estimated at 17$48 \%, 39,40$ and in the case of removable dentureusers at $23-51.2 \% .{ }^{13,27,41}$ In several studies, $S$. aureus was isolated on the pharyngeal mucosa in the study and the control group with similar frequency $(10.3 \%$ and $11.1 \%$, respectively). The differences concerned denture microniche, where the incidence of $S$. aureus was $22.4 \%$ in kidney recipients, whereas none of the healthy individuals was its carrier. Moreover, in the study group the incidence of $S$. aureus on the denture plate was more than twofold than on the pharyngeal mucosa. These differences may be due to a more frequent administration of antibiotics in chronic patients than in healthy individuals. Jacson et al. ${ }^{42}$ reported similar na protezach osób stosujących przerwę nocną. Ruchome uzupełnienia protetyczne powinny być poddane zabiegom higienicznym i przechowywane $\mathrm{w}$ środowisku suchym $\mathrm{z}$ dostępem powietrza. ${ }^{30} \mathrm{~W}$ tym czasie błona śluzowa podłoża protetycznego ulega mechanicznemu oczyszczeniu przez język, wentylacji i regeneracji, a protezy umieszczone w środowisku suchym zapobiegają nadmiernemu rozrostowi drobnoustrojów, których część ginie z wysuszenia a w przypadku bakterii beztlenowych $\mathrm{z}$ powodu dostępu tlenu.

Bakterie Staphylococcus, które wyizolowano w toku przeprowadzonych badań to zarówno gatunki uznawane za niegroźne dla człowieka (S. lentus, S.hominis, S. capitis), jak i gatunki mogące wywołać choroby w sytuacji obniżenia odporności organizmu lub zaburzenia równowagi jego flory (S. aureus. S. epidermidis, $S$. lugdunensis, $S$. haemolyticus). Najczęstszym izolowanym gatunkiem zarówno w przypadku grupy badanej, jak i kontrolnej był S. epidermidis, występujący z podobną częstością na powierzchni protezy i błony śluzowej gardła. Gatunek ten, będąc integralnym składnikiem flory skóry i często błon śluzowych układu pokarmowego i oddechowego, pełni ważną rolę w regulacji tych skomplikowanych ekosystemów bakteryjnych, zapobiegając nadmiernemu rozrostowi innych gatunków drobnoustrojów. ${ }^{31}$ Pozytywne cechy S. epidermidis, uznawanego w przeszłości za gatunek całkowicie nieszkodliwy, zostały w ostatnich latach skonfrontowane $\mathrm{z}$ drugą naturą gronkowca, którego potencjał wywoływania chorób jak dziś wiadomo jest niemalże zbliżony do potencjału $S$. aureus. ${ }^{32}$ Gronkowiec wywołuje zakażenia głównie u osób z obniżoną odpornością, do których należą osoby starsze, przewlekle chorzy, osoby odbywające chemioterapię czy przyjmujący leki immunosupresyjne. ${ }^{33,34}$ Poważne zakażenia z udziałem $S$. epidermidis mają niejednokrotnie charakter zakażeń szpitalnych i są związane $\mathrm{z}$ obecnością biomateriałów w ludzkim 
observations among juvenile patients with different types of myeloid leukaemias, in whom $S$. aureus was detected in the throat with the incidence of merely $5 \%$. Acrylic dentures create a much more stable environment favouring the accumulation of bacteria such as $S$. aureus in comparison with pharyngeal mucosa. ${ }^{43}$ It is confirmed by a smaller variability of the structure of Staphylococcal species isolated on dentures in the yearly period of observation in comparison with the bacterial structure originating from pharyngeal mucosa. It is noteworthy that among the controls the carrier state of $S$. aureus was not confirmed on the denture plate, even though the incidence of this species on the pharyngeal surface was $11.1 \%$. It can be concluded that appropriate awareness concerning denture cleanness, compliance with nightly breaks and good medical status that will exclude frequent visits to medical facilities all contribute to these differences. It has to be mentioned that Staphylococcal species isolated in the present study on denture plates are also identified in cases of bacteraemia in patients following kidney, liver, heart, pancreas, and lung transplantations. ${ }^{44}$ Some of them, like $S$. aureus, S. epidermidis or S. lugdunensis may be responsible for infections in distant organs in cases when oral mucosa damaged by the action of drugs or surgical procedures constitutes the gateway of infection. ${ }^{21}$ Also, bacteria isolated in denture plaque, including Staphylococci, may be implicated in aspiration pneumonia, play a vital role in exacerbations in patients with chronic obstructive pulmonary disease. ${ }^{26,45}$

In the present studies, apart from analyzing Staphylococcal bacterial composition in the study and the control group in a single swab, the distribution of strains of individual species was examined between three collections in 28 subjects undergoing a 6-12-month observation period. Basing on Fisher's test and obtained high correlation indicators, no significant ciele jak cewniki, endoprotezy, sztuczne zastawki serca. ${ }^{35}$ Chorobotwórczość S. epidermidis jest uzależniona od posiadania czynników wirulencji. Badania genetyczne jak MLST (Multilocus sequence typing), PFGE (Pulsedfield Gel Electrophoresis) czy RAPD (Random Amplification of Polymorphic DNA) pozwalają na wykrycie czy dany szczep posiada geny wirulencji. ${ }^{36}$ Cechą charakterystyczną $S$. epidermidis jest zdolność do przekazywania tych genów innym gatunkom, jak choćby $S$. aureus, który nabywając je, staje się bardziej odporny na czynniki środowiskowe, a niejednokrotnie także na liczne antybiotyki stosowane we współczesnych terapiach. ${ }^{37}$

Gronkowiec złocisty (S. aureus) jest drobnoustrojem o szczególnym znaczeniu w medycynie ze względu na udział w etiopatogenezie licznych zakażeń szpitalnych. ${ }^{38}$ U osób ogólnie zdrowych jego nosicielstwo w jamie nosowo-gardłowej jest szacowane na 17-48\%, 39,40 a w przypadku użytkowników ruchomych uzupełnień protetycznych na 23-51,2\%, $13,27,41$ W przeprowadzonych badaniach $S$. aureus był izolowany z powierzchni błony śluzowej gardła $\mathrm{w}$ grupie badanej i grupie kontrolnej z podobna częstością (odpowiednio 10,3\% i 11,1\%). Różnice dotyczyły mikroniszy protezy, gdzie u osób leczonych nerkozastępczo, $S$. aureus występował z częstością wynoszącą 22,4\%, natomiast u osób ogólnie zdrowych nie stwierdzono żadnego przypadku jego nosicielstwa. Ponadto w grupie badanej izolacja $S$. aureus na protezie była ponad dwukrotnie częstsza niż z powierzchni błony śluzowej gardła. Powyższe różnice mogą być podyktowane częstszym przyjmowaniem antybiotyków u pacjentów przewlekle chorych niż w populacji osób zdrowych. Podobne obserwacje mieli Jacson $i$ wsp., ${ }^{42}$ którzy u pacjentów młodocianych z różnymi postaciami białaczek szpikowych wykrywali $S$. aureus w gardle z częstością wynoszącą zaledwie 5\%. Protezy akrylowe stanowią środowisko o wiele bardziej stabilne 
differences in the incidence of dominating species (S. epidermidis, S. warneri, S. aureus) in subsequent collections were revealed on dentures. It clearly indicates that the environment of removable dental prostheses is stable over several to a dozen or so months and protects bacteria living in it. In the case of the pharyngeal microniche, however, the obtained results were suggestive of a tendency to maintain a relatively constant number of strains in the general population of isolated species in subsequent collections (high correlation parameters), as well as evident differences in the incidence of dominating species $(S$. epidermidis, $S$. warneri, $S$. haemolyticus). Among them, a dramatic drop in the number of isolations was observed, only to increase in subsequent collections. The most characteristic was the progressive drop in the incidence of $S$. epidermidis. These differences observed between the studied periods indicate that unlike the denture plate, pharynx is a microniche with a much higher variability of bacterial flora, at least for some species. This may be due to the exogenous influences (physical and chemical conditions in the oral cavity), and endogenous ones related to the general condition of the human body and administered medication.

\section{Conclusion}

The presented results show the issues of microbiology of removable dentures in users following a kidney transplant procedure in a different perspective. The denture plate contacting the mucosa is a stable environment, favouring the growth and proliferation of Staphylococci to a much greater extent than the pharyngeal mucosa. The preoperative time of denture wear in kidney recipients was correlated with the number of isolated Staphylococcal strains. In the first year following the transplantation procedure the structure of bacterial species on the denture i sprzyjające dla akumulacji bakterii takich jak $S$. aureus niż powierzchnia błony śluzowej gardła. ${ }^{43}$ Świadczy o tym mniejsza zmienność $\mathrm{W}$ strukturze gatunkowej izolowanych z powierzchni protez gronkowców w trakcie rocznego okresu obserwacji w porównaniu ze strukturą bakterii z powierzchni błony śluzowej gardła. Co ciekawe, u osób z grupy kontrolnej nie stwierdzono nosicielstwa $S$. aureus na powierzchni protezy, mimo iż częstość przypadków izolacji tego gatunku z powierzchni gardła wynosiła 11,1\%. Wnioskować można, iż odpowiednia świadomość utrzymywania protez $\mathrm{w}$ należytej czystości, stosowania przerwy nocnej i dobry stan ogólny, pozwalający na zredukowanie do minimum wizyt w placówkach ochrony zdrowia przyczyniają się do występowania powyższych różnic. Na uwagę zasługuje również fakt, iż izolowane w niniejszych badaniach gatunki Staphylococcus z powierzchni protez, są wykrywane także w przypadku bakteriemii osób po przeszczepach narządowych nerek, wątroby, serca, trzustki oraz płuc. ${ }^{44}$ Część z nich jak $S$. aureus, $S$. epidermidis czy $S$. lugdunensis może być również przyczyną infekcji w odległych narządach, gdzie wrota zakażenia stanowi uszkodzona działaniem leków lub zabiegów chirurgicznych błona śluzowa jamy ustnej. ${ }^{21}$ Dodatkowo bakterie izolowane z płytki bakteryjnej protez, do których także należą gronkowce, bywają przyczyną aspiracyjnego zapalenia płuc oraz pełnią istotną rolę $\mathrm{w}$ zaostrzeniach u osób z przewlekłą obturacyjną chorobą płuc. ${ }^{26,45}$

W niniejszych badaniach oprócz analizy bakteryjnego składu gronkowcowego grupy badanej i kontrolnej w zakresie pojedynczego wymazu, zbadano również rozkład szczepów poszczególnych gatunków pomiędzy trzema pobraniami u 28 osób objętych 6-12 miesięczną obserwacją. W przypadku protez, na podstawie wyniku testu Fishera oraz uzyskanych wysokich wskaźników korelacji, nie stwierdzono istotnych różnic w częstości 
plate contacting the mucosa did not manifest significant variations in subsequent collections, unlike the pharyngeal mucosa, where the incidence of dominating species underwent definite alterations over time. The conducted studies did not detect any correlation between the quality of denture hygiene or the protocol of their circadian use and the number of strains colonizing the prosthetic material. When both the pharyngeal and denture microniches were examined, $S$. epidermidis was found to be the dominant species in the study and the control groups; the number of its isolation tended to decrease in the first year postoperatively.

The issue of microbiology of the oral cavity and foreign bodies dwelling in it without question requires further research. Molecular biology methods will have to be implemented to give a much wider view on the functional mechanics of this complex ecosystem, which in the case of chronic patients would constitute a source of information of high clinical value.

\section{Podsumowanie}

Przedstawione wyniki badań rzucają nowe światło na zagadnienia związane $\mathrm{z}$ mikrobiologią ruchomych uzupełnień protetycznych w grupie osób leczonych nerkozastępczo przy pomocy przeszczepu narządowego. Powierzchnia dośluzowa płyty protezy stanowi środowisko stabilne, sprzyjające wzrostowi i rozplemowi bakterii Staphylococcus w większym stopniu niż powierzchnia błony występowania dominujących gatunków S. epidermidis, S. warneri, S. aureus w kolejnych pobraniach. Wskazuje to jednoznacznie, iż środowisko ruchomych uzupełnień protetycznych jest stabilne na przestrzeni kilku do kilkunastu miesięcy i zapewnia ochronę dla bakterii, które w nim bytują. Nieco inaczej było w przypadku mikroniszy gardła, gdzie uzyskano wyniki świadczące zarówno o tendencji do utrzymywania względnie stałej liczby szczepów w generalnej populacji wyizolowanych gatunków w kolejnych pobraniach (wysokie wskaźniki korelacji), jak i wyniki wykazujące wyraźne różnice w częstości występowania gatunków dominujących (S. epidermidis, S. warneri, S. haemolyticus). Wśród nich obserwowano zarówno znaczny spadek izolacji, jak i ich wzrost w kolejnych pobraniach. Najbardziej znamienny był progresywny spadek częstości występowania gatunku $S$. epidermidis. Powyższe różnice między badanymi okresami wskazują, iż w przeciwieństwie do powierzchni protez, gardło stanowi przynajmniej dla części gatunków mikroniszę o dużo większej zmienności flory bakteryjnej, co może wynikać zarówno z wpływu czynników zewnętrznych (warunki fizyko-chemiczne jamy ustnej) oraz wewnętrznych, które związane są z ogólną kondycją ludzkiego organizmu i przyjmowanymi lekami.

śluzowej gardła. U pacjentów leczonych nerkozastępczo przed przeszczepem czas użytkowania danej protezy był skorelowany z liczbą izolowanych szczepów gronkowców. W pierwszym roku po przeszczepie, struktura gatunkowa powierzchni dośluzowej protez nie wykazywała istotnych zmian w kolejnych pobraniach w odróżnieniu od powierzchni gardła, gdzie częstość występowania dominujących gatunków ulegała znacznym zmianom w czasie. Przeprowadzone badania nie wykryły 
związków między jakością higieny protez czy schematem ich użytkowania w przerwie nocnej z liczbą szczepów kolonizujących tworzywo. W badaniu mikronisz gardła i protez stomatologicznych, gatunkiem dominującym zarówno w grupie badanej, jak i kontrolnej był $S$. epidermidis, którego częstość izolacji malała w pierwszym roku po przeszczepie.
Kwestia mikrobiologii jamy ustnej i obecnych w niej ciał obcych niewątpliwie wymaga dalszych badań i uzupełnienia o metody biologii molekularnej dającej dużo większy pogląd na funkcjonowanie tego skomplikowanego ekosystemu, co w przypadku pacjentów przewlekle chorych stanowiłoby niezwykle wartościowe dla praktyki klinicznej źródło informacji.

\section{References / Piśmiennictwo}

1. Król E, Rutkowski B: Przewlekła choroba nerek - klasyfikacja, epidemiologia i diagnostyka. Forum Nefrol 2008; 1: 1-6.

2. Rutkowski B, Czekalski S, Sułowicz W i wsp.: Epidemiologia chorób nerek w Polsce: program pilotażowy PolNef. Przegl Lek 2004; 61: 22-24.

3. Król E, Rutkowski B, Czekalski $S$ i wsp.: Wczesne wykrywaniechorób nerek: wstępne wyniki programu pilotażowego PolNef. Przegl Lek 2005: 62, 690-698.

4. Król E, Czarniak P, Rutkowski B: Nadciśnienie tętnicze a przewlekła choroba nerek: wyniki Programu Wczesnego Wykrywania Chorób Nerek w Polsce (PolNef). Nadciśnienie Tętnicze 2007; 11: 114-122.

5. NKF K/DOQI Clinical Practice Guidelines for chronic kidney disease: evaluation, classification, and stratification. J Kidney Dis Am 2002; 39: S1-S266.

6. Tasaki M, Saito K, Nakagawa Y, Ikeda M et al.: 20-year analysis of kidney transplantation: a single center in Japan. Transplant Proc 2014; 46: 437-441.

7. Park WY, Kang SS, Jin K, Park SB et al.: Is the Clinical Outcome Good or Bad in Patients Hospitalized Within 1 Year After Kidney Transplantation? Transplant Proc 2018; 50: 1001-1004.

8. Alangaden GJ, Thyagarajan R, Gruber SA, Morawski $K$, et al: Infectious complications after kidney transplantation: current epidemiology and associated risk factors. Curr Transplant 2006; 20: 401-409.

9. Maraha B, Bonten H, Van Hooff H, Fiolet H, et al: Infectious complications and antibiotic use in renal transplant recipients during a 1-year follow-up. Clin Microbiol Infect 2001; 7: 619-625.

10. Moreno A, Cervera C, Gavalda J, Rovira et al.: Bloodstream infections among transplant recipients: results of a nationwide surveillance in Spain. Am J Transplant 2007; 7: 2579-2586.

11. Fayyaz M, Mirza IA, Ikram A, Hussain $A$, et al: Pathogens causing blood stream infections and their drug susceptibility profile in immunocompromised patients. J Coll Physicians Surg Pak 2013; 23: 848-851.

12. Cho S, Naber K, Hacker J, Ziebuhr W: Detection of the icaaADBC gene cluster and biofilm formation in Staphylococcus epidermidis isolates from catheter-related urinary tract infections. Int. J Antimicrob Agents. 2002; 19: 570-575.

13. Otto $M$ : Staphylococcal infections: mechanisms of biofilm formation and detachment as critical determinats of pathogenicity. Annu Rev Med 2013; 64: 175188.

14. Challacombe SJ, Percival RS, Marsh PD: Age-related changes in immunoglobulin isotypes in whole and parotid saliva and 
serum in healthy individuals. Oral Microbiol Immunol 1995; 10: 202-207.

15. Percival RS, Marsh PD, Challacombe SJ: Age-related changes in salivary antibodies to commensal oral and gut biota. Oral Microbiol Immunol 1997; 12: 57-63.

16. Henriksen BM, Ambjørnsen E, Axéll TE: Evaluation of a mucosal-plaque index (MPS) designed to assess oral care in groups of elderly. Spec Care Dentist 1999; 19: 154-157.

17. Becker K, Heilmann C, Peters G: Coagulasenegative staphylococci. Clin Microbiol Rev 2014; 27: 870-926.

18. Miyake $Y$, Iwai $M$, Sugai $M$, Miura $K$, et al: Incidence and characterization of Staphylococcus aureus from tongues of children. J Dent Res 1991; 70: 1045-1047.

19. Jacson MS, Bagg J, Gupta MN, Sturrock RD: Oral carriage of staphylococci in patients with rheumatoid arthritis. Reumatol 1999; 38: 572575.

20. Didilescu AC, Skaug N, Marica C, Didilescou $C$, et at.: Respiratory pathogens in dental plaque of hospitalized patients with chronic lung disease. Clin Oral Investig 2005; 9: 141147.

21. Smith AJ, Jackson MS, Bagg J: The ecology of Staphylococcus species in the oral cavity. J Med Microbiol 2001; 50: 940-946.

22. Wertheim H, Melles D, Vos M, van Leeueven $W$, et al: The role of nasal carriage in Staphylococcus aureus infections. Lancet Infect Dis 2005; 5: 751-762.

23. Ribeiro DG, Pavarina AC, Dovigo $L N$, Machado AL et al.: Prevalence of Candida spp. associated with bacteria species on complete dentures. Gerodontol 2012; 29: 203-208.

24. Samaranayake LP: Normal oral flora, the oral ecosystem and plaque biofilms. Essential microbiology for dentistry; 3rd edn. Philadelphia: Elsevier; 2006.

25. Rasiah IA, Wong L, Andrerson SA, Sissons $\mathrm{CH}$ : Variation in bacterial DGGE patterns from human saliva: over time, between individuals and corresponding dental plaque microcosms. Arch Oral Biol 2005; 50: 779787.

26. O'Donnell LE, Smith K, Williams C, Nile CJ et al.: Dentures are a Reservoir for Respiratory Pathogens. J Prosthodont 2016; 25: 99-104.

27. Dahlen $G$ : Bacterial infections of the oral mucosa. Periodontol 2009; 49: 13-38.

28. Ziebolz D, Hraský V, Goralczyk A, Hornecker $E$ : Dental care and oral health in solid organ transplant recipients: a single center crosssectional study and survey of German transplant centers. Transpl Int 2011; 24: 11791188.

29. Yusof Z, Isa Z: Periodontal status of teeth in contact with denture in removable partial denture wearers. J Oral Rehabil 1994; 21: 77-86.

30. Spiechowicz E: Protezy całkowite, Protetyka Stomatologiczna, PZWL Rozdział stomatopatie protetyczne, strony 517-545.

31. Nguyen TH, Park MD, Otto M: Host Response to Staphylococcus epidermidis Colonization and Infections. Front Cell Infect Microbiol 2017; 21: 90.

32. Brescó MS, Harris LG,Thompson K, StanicB et al.: Pathogenic Mechanisms and Host Interactions in Staphylococcuc epidermidis Device-Related Infection. Front Microbiol 2017; 8: 1-24.

33. Majchrzak K, Mierzwińska-Nastalska E, Chmura A, Kwiatkowski A i wsp.: Comparison of Staphylococcal Flora in Denture Plaque and the Surface of the Pharyngeal Mucous Membrane in Kidney Transplant Recipients. Transplant Proc 2016; 48: 1590-1597.

34. Becker K, Heilmann Ch, Peters G: CoagulaseNegative Staphylococci. Clin Microbiol Rev 2014; 27: 870- 926.

35. Von Eiff C, Jansem B, Kohnen W, Becker K: Infections associated with medical devices: pathogenesis, management and prophylaxis. Drugs 2005; 48: 179-214.

36. Tsen HY, Li SC, Chiang YC, Tsai SW: Strain Discrimination of Staphylococcus aureus 
Using Superantigen Profiles. Methods Mol Biol 2016; 1396: 35-49.

37. Diep BA, Gill SR, Chang RF, Phan TH et al.: Complete genome sequence of USA300, an epidemic clone of community-acquired meticillin-resistant Staphylococcus aureus. Lancet 2006; 4: 731-739.

38. Camargo LF, Marra AR, Pignatari AC, Sukiennik $T$ et al.: Nosocomial bloodstream infections in a nationwide study: comparison between solid organ transplant patients and the general population. Transpl Infect Dis 2015; 17: 308-313.

39. Murphy RA: Elastase production by oral staphylococci. J Dent Res 1974; 36: 832-834.

40. Knighton HT: Coagulase-positive staphylococci in oral and nasal areas of dental students: a fouryear study. J Dent Res 1965; 44: 467-470.

41. Majchrzak K, Mierzwińska-Nastalska E, Chmura A, Kwiatkowski A i wsp.: Clinical and Microbiological Evaluation of Removable Prosthetic Restorations in Patients Treated With an Organ Transplant. Transplant Proc
2016; 48: 1418-1422.

42. Jacson MS, Bagg J, Kennedy H, Michie J: Staphylococci in the oral flora of healthy children and those receiving treatment for malignant disease. Microb Ecol Health Dis 2000; 12: 60-64.

43. Sumi Y, Kagami H, Ohtsuka Y, Kakinoki Y et al.: High correlation between the bacterial species in denture plaque and pharyngeal microflora. Gerodontol 2003; 20: 84-87.

44. Kritikos A, Manuel O: Bloodstream infections after solid-organ transplantation. Virulence 2016; 7: 329-340.

45. Przybytowska D, Mierzwińska-Nastalska E, Swoboda-Kopeć E, Rubinsztajn $R$ i wsp.: Potential respiratory pathogens colonisation of the denture plaque of patients with chronic obstructive pulmonary disease. Gerodontol 2016; 33: 322-327.

Zaakceptowano do druku: 31.01.2019 r.

Adres autorów: 02-004 Warszawa, ul. Chałubińskiego 5. (c) Zarząd Główny PTS 2019. 